\title{
Potensi Bacillus cereus dalam produksi biosurfaktan
}

\author{
Potentials of Bacillus cereus in biosurfactant production
}

\author{
Nur Asni Setiani*, Nia Agustina, Irma Mardiah, Syarif Hamdani, Dewi Astriany \\ Program Studi Sarjana Farmasi, Sekolah Tinggi Farmasi Indonesia \\ Jalan Soekarno Hatta No.354 Bandung, Indonesia-40266 \\ *Email: nur.asni@stfi.ac.id
}

Diterima 17 September $2019 \quad$ Disetujui 16 Desember 2020

\section{INTISARI}

Biosurfaktan dari mikroorganisme bersifat stabil secara fisika kimia, mudah terurai, dan memiliki toksisitas rendah sehingga dapat digunakan sebagai antibakteri dalam industri farmasi. Penelitian ini bertujuan menguji aktivitas emulsifikasi dan karakterisasi biosurfaktan dari Bacillus cereus. Uji hemolisis dan oli spreading dilakukan sebagai penapisan awal. Produksi biosurfaktan dilakukan dengan cara menumbuhkan bakteri pada media yang diperkaya minyak dengan sistem shaker selama 7 hari pada suhu $25^{\circ} \mathrm{C}$. Supernatan diuji aktivitas biosurfaktan melalui indeks emulsifikasi dan dikarakterisasi menggunakan kromatografi lapis tipis serta pengujian kualitatif antibakteri menggunakan Escherichia coli (Gram negatif) dan Staphylococcus aureus (Gram positif). Bacillus cereus dapat menghidrolisis darah dan menyebarkan lapisan minyak Hasil indeks emulsifikasi pada hari ke 0, 1, 3, 5, dan 7 secara berurutan 44,83\%, 48,28\%, $51,72 \%$, 46,43\%, dan 51,50\%. Hasil KLT yang ditandai noda merah dengan penampak ninhidrin menunjukkan golongan lipopeptida. Pengujian antibakteri menunjukkan terbentuknya zona bening di sekitar kertas cakram. Bacillus cereus dapat menghasilkan biosurfaktan golongan lipopeptida dengan indeks emulsifikasi terbesar 51,72\% pada hari ketiga dan memiliki aktivitas antibakteri.

Kata kunci: antibakteri, Bacillus cereus, Biosurfaktan, emulsifikasi, lipopeptida

\begin{abstract}
Biosurfactants from microorganisms are physically and chemically stable, environment friendly, biodegradable, and have low toxicity that can be used as antibacterial in the pharmaceutical industry. The purpose of this research was to examine the emulsification and characterization of biosurfactant from Bacillus cereus. Hemolysis and spreading oil tests were performed as an initial screening. Biosurfactant production was carried out by growing bacteria on oil-enriched media with shaker system for 7 days at $25^{\circ} \mathrm{C}$. The supernatant was measured for biosurfactant activity through an emulsification index and characterized using thin layer chromatography and antibacterial qualitative testing using Escherichia coli (Gram negative) and Staphylococcus aureus (Gram positive). The emulsification index on days 0, 1, 3, 5, and 7 showed percentage in sequence $44,83 \%, 48,28 \%, 51,72 \%, 46,43 \%$, and $51,50 \%$. The formation of red stains on TLC plates with ninhydrin appearance showed lipopeptide groups. Antibacterial testing showed the formation of clear zones around the disk paper. Bacillus cereus can produce lipopeptide biosurfactants with the greatest emulsification index of $51.72 \%$ on the third day and has antibacterial activity.
\end{abstract}

Keywords: antibacterial, Bacillus cereus, Biosurfactant, emulsification, lipopeptide 


\section{PENDAHULUAN}

Industri surfaktan di Indonesia masih sangat terbatas, padahal penggunaannya semakin meningkat. Menurut data dari Pusat Kimia Lembaga Ilmu Pengetahuan Indonesia (LIPI), Indonesia membutuhkan surfaktan sekitar 95.000 ton per tahun sementara kapasitas produksi dalam negeri hanya sekitar 55.000 ton per tahun sehingga sebanyak 44.500 ton surfaktan masih diimpor. Itupun surfaktan yang diproduksi dari Petroleum (Furi \& Coniwanti, 2012). Petroleum ini bersifat tidak ramah lingkungan sehingga mengakibatkan pencemaran karena sulit terurai oleh mikroorganisme (Fakruddin, 2012).

Biosurfaktan disintesis secara ekstraseluler oleh mikroorganisme dan memiliki aktivitas sebagai penurun tegangan permukaan sehingga dapat dijadikan sebagai sumber energi alternatif (Sari et al., 2015). Biosurfaktan dari mikroorganisme bersifat stabil secara fisika kimia, mudah terurai, serta toksisitasnya rendah sehingga dapat digunakan dalam industri farmasi (Ciccyliona \& Nawfa, 2012).

Aplikasi biosurfaktan di bidang medis menurut Mukherjee et al. (2006) diantaranya ialah aktivitas antimikroba. Biosurfaktan dapat bersifat toksik terhadap permeabilitas membran sel seperti halnya efek detergen. Biosurfaktan yang diproduksi oleh Bacillus circulans yang memiliki aktivitas antimikroba potensial melawan patogen gram positif dan gram negatif membuatnya berguna untuk mengobati banyak penyakit seperti agen terapeutik dan probiotik. Biosurfaktan juga memiliki aktivitas antikanker, agen anti-adesif, membantu sistem imun, aktivitas antivirus, transfer gen, menstimulus metabolisme stem fibroblast, dan lain sebagainya (Fakruddin, 2012).

Beragam manfaat dan kegunaan dari biosurfaktan menyebabkan perlu adanya eksplorasi dari berbagai strain bakteri yang dapat menghasilkan biosurfaktan dalam jumlah yang banyak dan memiliki aktivitas yang sama dengan surfaktan kimia yang biasa digunakan dalam industri. Bakteri dari genus Bacillus berpotensi untuk menghasilkan biosurfaktan golongan lipopeptida seperti iturin, fengisin, dan surfaktin yang dapat digunakan dalam industri (Plaza et al., 2015). Bacillus cereus menjadi fokus penelitian untuk mengetahui potensinya sebagai penghasil biosurfaktan melaui uji hemolisis, oil spreading, dan aktivitas biosurfaktan, serta dilakukan karakterisasi biosurfaktan yang dihasilkannya.

\section{MATERI DAN METODE}

\section{Tempat dan waktu penelitian}

Penelitian ini dilakukan di Laboratorium Mikrobiologi Sekolah Tinggi Farmasi Indonesia, Jalan Soekarno Hatta No.354 Bandung pada bulan Januari sampai Juli 2019.

\section{Bahan dan alat}

Bahan uji pada penelitian ini adalah bakteri Bacillus cereus yang terdapat di Sekolah Tinggi Farmasi Indonesia, serta bakteri Escherichia coli dan Staphylococcus aureus untuk uji aktivitas antibakteri. Media yang digunakan antara lain Nutrient Agar (Oxoid), Nutrient Broth (Oxoid), Blood Base Agar (Oxoid), Mueller Hinton Agar (Oxoid), darah kuda segar, dan minyak kelapa. Sedangkan bahan kimia yang digunakan diantaranya metanol, kloroform, alkohol 70\%, $\mathrm{HCl}, \mathrm{NaOH}$, ninhidrin, aseton dan spirtus. Bahan lainnya berupa tips dan plat KLT.

Alat yang digunakan antara lain spektrofotometer UV-Vis (Shimadzu), inkubator (Memmert), Laminar Air Flow (ERSA Scientific), autoklaf (GEA), shaker, vortex (Barnstead thermolyne), $\mathrm{pH}$ meter (Mettler Toledo Seven), neraca analitik (Ohaus), lemari pendingin (GEA), oven, mikropipet, chamber, kawat ose, falcon (Nest tube), pipa kapiler, dan alat-alat gelas (pyrex).

\section{Metode}

\section{a. Penapisan bakteri penghasil biosurfaktan}

Pengujian awal Bacillus cereus sebagai penghasil biosurfaktan dilakukan melalui uji hemolisis dan oil spreading technique.

$\underline{\text { Uji hemolisis }}$ 
Sebanyak 1,5 ml darah segar kuda steril dipipet ke dalam labu Erlenmeyer yang berisi $100 \mathrm{~mL}$ media dasar agar darah, dihomogenkan, dituang ke dalam cawan petri steril, dan ditunggu hingga memadat. Isolat bakteri diinokulasikan dengan metode gores ke atas media agar darah dan diinkubasi selama $24-48$ jam pada suhu $37^{\circ} \mathrm{C}$. Pengamatan dilakukan dengan mengecek keberadaan zona hemolisis dan perubahan warna dari aktivitas bakteri uji (Das et al., 2008).

\section{Oil spreading technique}

Sebanyak 30mL akuades dituangkan ke dalam cawan Petri kemudian ditambahkan $1 \mathrm{~mL}$ minyak kelapa di bagian tengah cawan Petri tersebut. Setelah itu, ditambahkan $20 \mu \mathrm{L}$ supernatan dari kultur bakteri. Bakteri penghasil biosurfaktan dapat menggantikan minyak dan menyebar di dalam air. Diameter dari zona bening di permukaan diukur dan dibandingkan dengan kontrol yang menggunakan media tanpa diinokulasi supernatan bakteri (Arora et al., 2015).

\section{b. Produksi biosurfaktan}

Suspensi bakteri Bacillus cereus diperoleh dari subkultur dalam media Nutrient Broth yang sudah diinkubasi pada suhu $37^{\circ} \mathrm{C}$ selama 48 jam. Sebanyak $1 \mathrm{~mL}$ suspensi bakteri diinokulasi ke dalam $100 \mathrm{~mL}$ media Nutrient Broth yang mengandung 3,3 mL minyak kelapa sebagai sumber substrat. Kultur bakteri diinkubasi di suhu $25^{\circ} \mathrm{C}$ selama 7 hari pada shaker. Pengamatan dilakukan pada T0, T1, T3, T5, dan T7 (Sari et al, 2015). Pemisahan biosurfaktan dengan sel bakteri dilakukan dengan cara disentrifugasi pada 3600rpm selama 20 menit. Supernatan yang terbentuk selanjutnya digunakan untuk uji aktivitas biosurfaktan, Kromatografi Lapis Tipis, dan uji antibakteri.

\section{c. Pengukuran aktivitas emulsifikasi biosurfaktan}

Sebanyak $2 \mathrm{~mL}$ supernatan ditambah dengan $1 \mathrm{~mL}$ minyak kelapa kemudian divorteks selama 1 menit dan dibiarkan selama 24 jam. Pengamatan dilakukan secara visual dengan melihat lapisan emulsi yang terbentuk. Reaksi emulsifikasi ditandai dengan adanya suatu layer emulsifikasi antara crude oil dan media yang berisi biosurfaktan. Selanjutnya dihitung nilai index emulsifikasi (E24) yang merupakan persentase dari tinggi lapisan emulsi dibagi dengan tinggi total larutan (Kurniati, 2016) dengan rumus :

$$
\text { Emulsifikasi index }(E 24)=\frac{\text { tinggi lapisan emulsi }}{\text { tinggi total larutan }} \times 100 \%
$$

\section{d. Karakterisasi biosurfaktan Kromatografi Lapis Tipis (KLT)}

Supernatan yang mengandung biosurfaktan diuji kromatografi lapis tipis (KLT) menggunakan eluen kloroform, metanol, dan air dengan perbandingan 65:25:4 (v:v:v). Spot yang terbentuk divisualisasikan dengan reagen ninhidrin (250 mg dalam $50 \mathrm{~mL}$ aseton) dibawah sinar UV pada panjang gelombang $254 \mathrm{~nm}$ dan 366nm (Das et al., 2008).

\section{e. Pengujian aktivitas antibakteri}

Pengujian dilakukukan menggunakan metode difusi cakram pada media Mueller Hinton Agar dengan bakteri uji Escherichia coli (Gram negatif) dan Staphylococcus aureus (Gram positif) yang dikultur terlebih dahulu pada media Nutrient Broth dan diinkubasi pada suhu $37^{\circ} \mathrm{C}$ selama overnight. Masing-masing $1 \mathrm{~mL}$ suspensi bakteri diinokulasikan ke dalam cawan Petri steril berbeda, ditambahkan media Mueller Hinton Agar, dihomogenkan, dan dibiarkan hingga memadat. Kertas cakram berisi $20 \mu \mathrm{L}$ crude biosurfaktan, kloramfenikol $(10 \mu \mathrm{L})$ sebagai kontrol positif, dan akuades sebagai kontrol negatif diletakkan di atas lapisan agar dengan pengaturan jarak. Kultur diinkubasi pada inkubator suhu $37^{\circ} \mathrm{C}$ selama 24 jam, hasil positif ditandai dengan terbentuknya zona bening di sekitar kertas cakram (Das et al,. 2008).

\section{HASIL}

Penapisan dilakukan menggunakan uji hemolisis dan uji oil spreading. Prinsip pengujian hemolisis adalah terjadinya perubahan warna koloni bakteri yang diinokulasi di atas agar darah dan terbentuknya zona bening di sekitar koloni. Bacillus cereus menunjukkan hasil positif yang 
berarti mampu melisiskan sel-sel darah merah. Oil spreading merupakan metode cepat, mudah dan sensitif digunakan untuk mendeteksi aktivitas biosurfaktan dalam konsentrasi rendah. Secara kualitatif, hasil uji hemolisis dan oil spreading dapat dilihat pada Gambar 1.

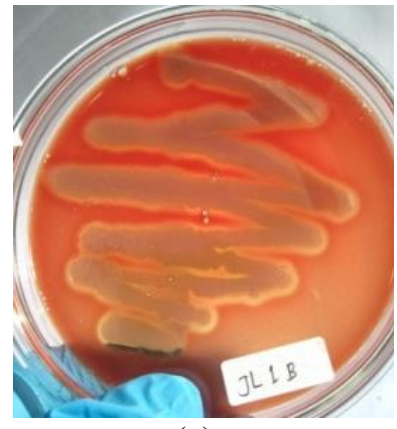

(a)

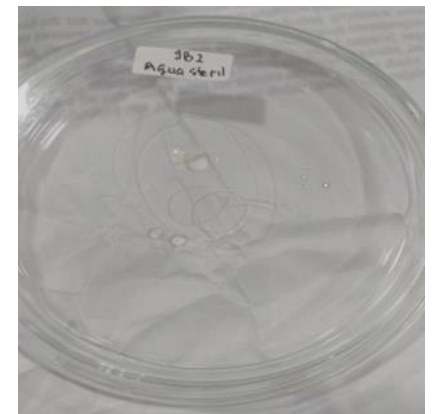

(b)
Gambar 1. Hasil penapisan Bacillus cereus melalui uji hemolisis $\beta$ pada agar darah (a) dan oil spreading (b)

Prinsip uji emulsifikasi yaitu perbandingan tinggi minyak yang teremulsi di dalam air dengan tinggi campuran minyak dan air. Emulsi yang terjadi pada permukaan cairan terjadi karena kemampuan senyawa surfaktan yang mampu menggabungkan senyawa polar (cairan media Nutrient Broth) dengan senyawa campuran (minyak kelapa). Gambar 2 menunjukkan diagram indeks emulsifikasi dari Bacillus cereus pada T0, T1, T3, T5, dan T7.

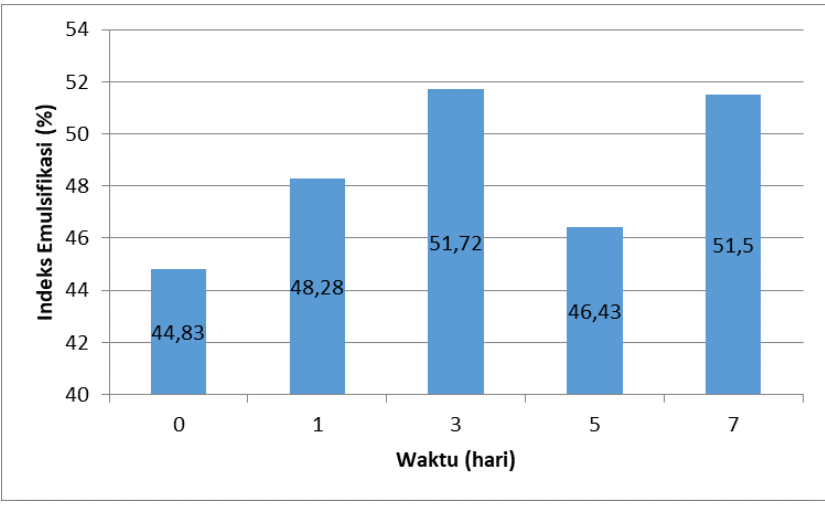

Gambar 2. Indeks emulsifikasi (E24) Bacillus cereus pada variasi waktu inkubasi

Kromatografi Lapis Tipis (KLT) merupakan uji kualitatif untuk mengetahui sifat kimia biosurfaktan berdasarkan tingkat kepolaran. Dengan menggunakan pelarut kloroform, methanol, dan air dengan perbandingan 65:25:4 (v:v:v), serta pengamatan di bawah sinar UV 254nm, 366nm, dan penambahan ninhidrin, menunjukkan adanya bercak seperti pada Gambar 3.

Pengujian aktivitas antibakteri dilakukan secara kualitatif menggunakan metode difusi dengan melihat zona hambat yang terbentuk di sekitar kertas cakram. Hasil uji antibakteri dapat dilihat pada Gambar 4.

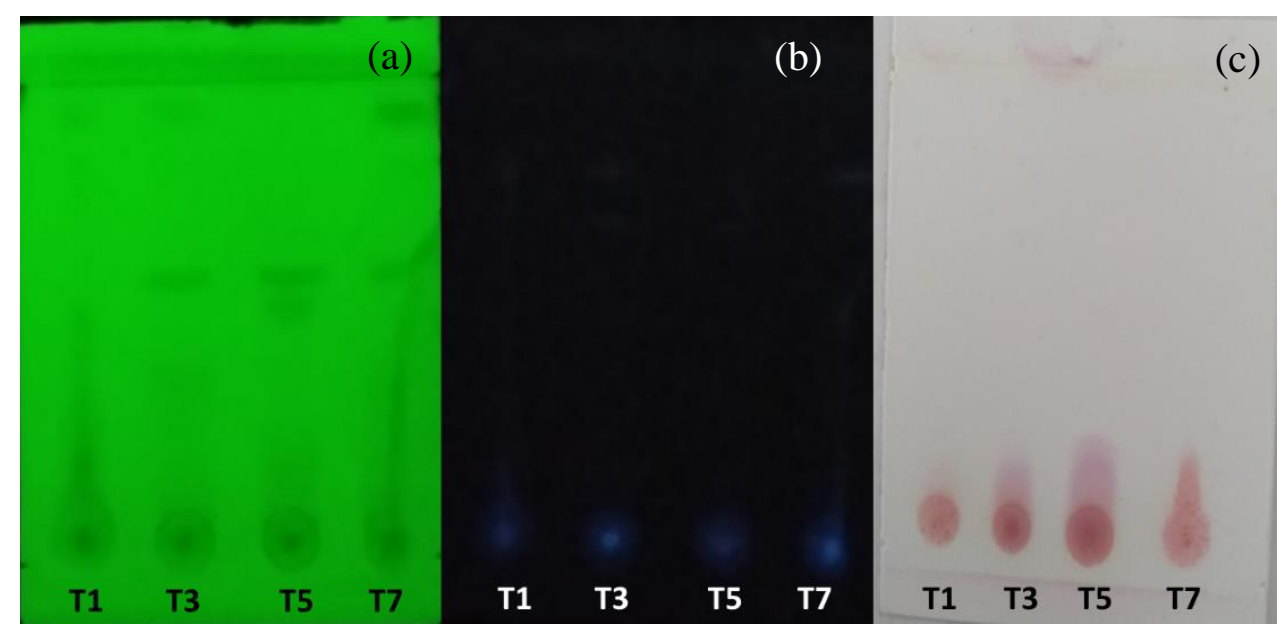

Gambar 3. Hasil KLT menggunakan fase gerak kloroform: metanol: air (65:25:4) dibawah UV 254nm (a) $366 \mathrm{~nm}$ (b) dan penampak bercak Ninhidrin (c) pada supernatan Bacillus cereus 


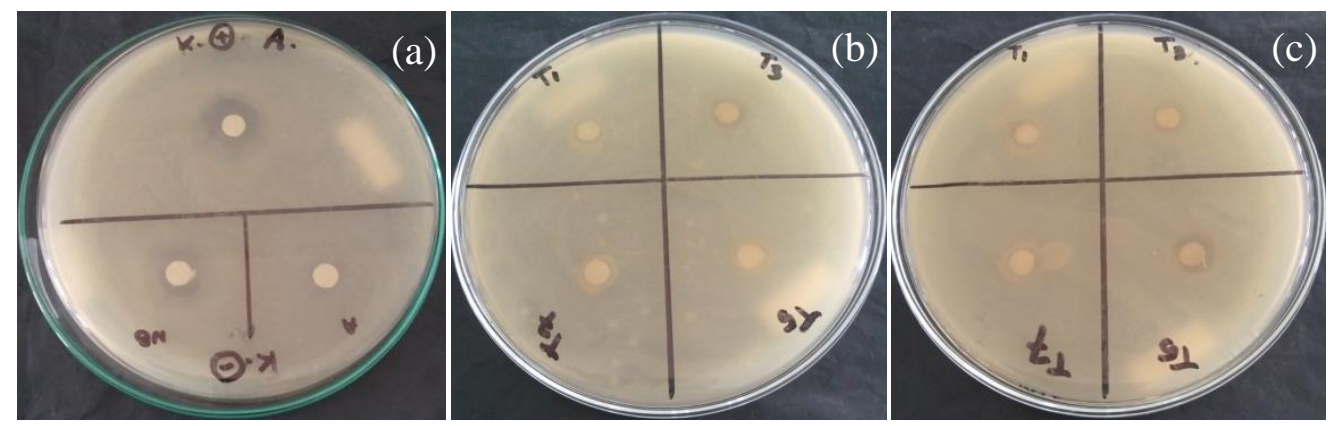

Gambar 4. Uji aktivitas antibakteri dari crude surfaktan Bacillus cereus (a) kontrol (b) Staphylococcus aureus (c) Escherichia coli

\section{PEMBAHASAN}

Bacillus cereus menghasilkan $\beta$-hemolisis (zona bening) yang menandakan adanya potensi biosurfaktan. Bacillus cereus merupakan bakteri gram positif yang menghasilkan tiga enterotoksin pembentuk pori, seperti hemolisin BL (HBL), enterotoksin nonhemolitik (NHE) dan sitotoksin $\mathrm{K}$ (Bottone, 2010). Zona bening yang terbentuk menandakan terjadinya mekanisme kontak antara sel bakteri dan eritrosit sehingga menyebabkan lisis dan terbentuk zona bening. Hasil penelitian Youssef dkk. (2004) menyatakan bahwa terdapat hubungan linear antara diameter zona bening dan konsentrasi biosurfaktan yang dihasilkan. Aktivitas hemolitik biosurfaktan dapat terjadi melalui dua mekanisme yaitu larutnya membran secara normal pada konsentrasi biosurfaktan yang tinggi atau meningkatnya permeabilitas membran terhadap zat terlarut berukuran kecil pada biosurfaktan konsentrasi rendah sehingga menyebabkan lisis osmotik. Bakteri lainnya tidak menunjukkan aktivitas hemolitik. Hal ini kemungkinan hemolitik yang disekresikan oleh sel-sel bakteri tidak dapat melisiskan eritrosit atau hemolisin tidak disekresikan, tetapi hanya melekat pada permukaan sel (Högfors-Rönnholm \& Wiklund, 2010).

Hasil uji oil spreading positif ditunjukkan dengan lapisan minyak menyebar membentuk zona bening Ketika supernatan diteteskan, lapisan minyak teremulsi dan membentuk misel-misel yang menyebar ke permukaan lapisan minyak. Misel terbentuk karena bagian hidrofobik dan hidrofilik pada supernatan menyatu, menyebabkan terjadinya tekanan antara bagian hidrofobik dan hidrofilik sehingga tegangan permukaanya turun (Techaoei et al., 2011).

Kemampuan emulsifikasi dari biosurfaktan yang dihasilkan Bacillus cereus mencapai $51,72 \%$ (Gambar 2). Nilai indeks emulsi yang besar menunjukkan sifat dari biosurfaktan. Wilumsen \& Karlson (1997) mengatakan bahwa nilai E24 mengindikasikan stabilitas dari emulsi dan jika menghasilkan nilai di atas 50\% dapat dinyatakan sebagai penghasil biosurfaktan yang baik.

Indeks emulsifikasi tertinggi diperoleh pada hari ke-3 (T3). Hal ini dapat menjadi dasar untuk menentukan waktu inkubasi terbaik dalam menghasilkan biosurfaktan. Walaupun, masih mengalami penurunan dan peningkatan yang fluktuatif. Jumlah biosurfaktan yang dihasilkan bergantung dari kemampuan mikroorganisme menggunakan nutrisi yang tersedia. Faktor lingkungan seperti suhu, $\mathrm{pH}$, aerasi dan agitasi juga berpengaruh terhadap pertumbuhan bakteri dan kemampuannya dalam menghasilkan biosurfaktan (Utami et al., 2013).

Kemampuan emulsifikasi bakteri dipengaruhi oleh struktur dan komponen yang dimiliki oleh biosurfaktan. Umumnya, biosurfaktan tersusun dari komponen gula, asam amino, asam lemak dan kelompok fungsional seperti asam karboksilat. Senyawa glikolipid (rhamnolipid, sophorolipid dan trehalolipid) merupakan contoh biosurfaktan yang terdiri dari gula yang berbeda dan terkait dengan asam lemak $\beta$-hidroksi, sedangkan lipopeptida (surfaktin, iturin, dan fengycin) terdiri atas sikloheptapeptida dengan asam amino yang terikat pada asam lemak dari rantai yang berbeda. Struktur ini menyebabkan 
biosurfaktan bersifat amfilitik dan dapat bercampur baik pada pelarut polar maupun nonpolar. Struktur amfilitik ini juga memungkinkan biosurfaktan dapat menurunkan tegangan permukaan dan tegangan antarmuka dua fase yang berbeda serta mampu membentuk emulsi. Kemampuan emulsifikasi ini merupakan tahapan yang penting untuk memudahkan pengambilan substrat hidrofobik oleh sel (Kurniati, 2016).

Berdasarkan hasil kromatografi lapis tipis pada Gambar 3, crude biosurfaktan dari masingmasing bakteri menunjukkan adanya bercak berpendar di atas pemukaan silika gel dibawah sinar UV $366 \mathrm{~nm}$. Senyawa biosurfaktan positif mengandung asam amino bebas ditunjukkan dengan terbentuknya warna. merah setelah penyemprotan ninhidrin dan pemanasan dengan oven pada suhu $100^{\circ} \mathrm{C}$. Hal ini menunjukkan adanya senyawa biosurfaktan yang termasuk golongan lipopeptida. Namun, adanya beberapa bercak pada plat silika dan spot tidak berbentuk bulat menandakan senyawa biosurfaktan belum murni masih berupa crude biosurfaktan sehingga perlu pemurnian lebih lanjut.

Pengamatan aktivitas antibakteri secara visual menunjukkan bahwa crude biosurfaktan yang dihasilkan Bacillus cereus dapat menghambat pertumbuhan bakteri gram positif (Staphylococcus aureus) maupun gram negatif (Escherichia coli) dengan terbentuknya zona bening disekitar kertas cakram. Perbedaan zona bening yang dihasilkan menunjukkan bahwa spektrum penghambatan bergantung pada jenis dan kekuatan senyawa antibakteri. Selain itu, aktivitas antibakteri juga dipengaruhi oleh konsentrasi kandungan senyawa metabolit, daya difusi, dan jenis bakteri yang dihambat.

\section{SIMPULAN}

Bacillus cereus berpotensi sebagai penghasil biosurfaktan golongan lipopeptida. Indeks emulsifikasi terbesar $51,72 \%$ pada hari ketiga dan memiliki aktivitas antibakteri.

\section{UCAPAN TERIMA KASIH}

Penulis mengucapkan terima kasih kepada Yayasan Hazanah atas bantuan dana Hibah Riset Dosen Pemula serta berbagai fasilitas yang telah diberikan pada program riset ini. Sampaikan ucapan terimakasih dengan kalimat yang baik dan benar.

\section{KEPUSTAKAAN}

Arora SK, Sony J, Sharma A, Taneja M. 2015. Production and characterization of biosurfactant from Pseudomonas spp. Int. J. Curr. Microbiol. App. Sci 4(1): 245-253.

Bottone EJ. 2010. Bacillus cereus, a Volatile Human Pathogen. Clinical Microbiology Reviews 23(2): 382-398.

Ciccyliona DY, Nawfa R. 2012. Pengaruh pH Terhadap Produksi Biosurfaktan oleh Bakteri Pseudomonas aeruginosa Lokal. J. Sains Dan Seni Pomits 1: 1-6.

Das P, Mukherjee S, Sen R. 2008. Antimicrobial potential of a lipopeptide biosurfactant derived from a marine Bacillus circulans. $J$ Appl Microbiol 104: 1675-1684.

Fakruddin Md. 2012. Biosurfactant: Production and Application. J Pet Environ Biotechnol 3 (4): 124 .

Furi TA, Coniwanti P. 2012. Pengaruh Perbedaan Ukuran Partikel dari Ampas Tebu dan Konsentrasi Natrium Bisulfit (NaHSO3) pada Proses Pembuatan Surfaktan. J. Tek. Kim 18.

Högfors-Rönnholm E， Wiklund T. 2010. Hemolytic Activity in Flavobacterium psychrophilum Is A Contact-Dependent, Two-Step Mechanism and Differently Expressed in Smooth And Rough Phenotypes. Microb. Pathog 49: 369-375.

Kurniati TH. 2016. Bakteri Penghasil Biosurfaktan dari Lingkungan Tercemar Limbah Minyak dan Potensinya dalam Mendegradasi Hidrokarbon Aromatik Polisiklik (HAP). Skripsi. Institut Pertanian Bogor, Bogor. 
Mukherjee S, Das P, Sen R. 2006. Towards commercial production of microbial surfactants. Trends Biotechnol 24: 509-515.

Plaza G, Chojniak J, Rudnicka K, Paraszkiewicz K, Berna, P. 2015. Detection of biosurfactants in Bacillus species: genes and products identification. Jurnal of Applied Microbiology 119: 1023-1034.

Sari M, Afiati F, Kusharyoto W. 2015. Potency of Oil Sludge Bacteria as a Producer of Biosurfactant and Antimicrobial Agents. Pros. Semin. Nas. Masy. Biodiversitas Indones. 1(1): 85-88.

Techaoei S, Lumyong S, Prathumpai W, Santiarwarn D, Leelapornpisid P. 2011. Screening characterization and stability of biosurfactant produced by Pseudomonas aeruginosa SCMU106 isolated from soil in Northern Thailand. Asian Journal of Biological Sciences 4(4): 340-351.

Utami DS, Priyani N, Erman M. 2013. Isolasi dan Uji Potensi Bakteri Tanah Pertanian Berastagi Sumatera Utara dalam Mendegradasi Fungisida Antracol Berbahan Aktif Propineb. Saintia Biologi 1(2): 1-7.

Willumsen PAE, Karlson U. 1997. Screening of bacteria, isolatedfrom PAH-contaminated soils, for production of biosurfactant andbioemulsifiers. Biodegradation 7: 415423.

Youssef NH, Duncana KE, Naglea DP, Savagea KN, Knapp RM, McInerney MJ. 2004. Comparison of methods to detect biosurfactant production by diverse microorganisms. J. Microbiol. Methods 56: 339-347. 